\title{
Modified microplate method for rapid and efficient estimation of siderophore produced by bacteria
}

\author{
Naveen Kumar Arora ${ }^{1}$ - Maya Verma ${ }^{1}$
}

Received: 8 August 2017/ Accepted: 9 October 2017/Published online: 26 October 2017

(c) The Author(s) 2017. This article is an open access publication

\begin{abstract}
In this study, siderophore production by various bacteria amongst the plant-growth-promoting rhizobacteria was quantified by a rapid and efficient method. In total, 23 siderophore-producing bacterial isolates/strains were taken to estimate their siderophore-producing ability by the standard method (chrome azurol sulphonate assay) as well as 96 well microplate method. Production of siderophore was estimated in percent siderophore unit by both the methods. It was observed that data obtained by both methods correlated positively with each other proving the correctness of microplate method. By the modified microplate method, siderophore production by several bacterial strains can be estimated both qualitatively and quantitatively at one go, saving time, chemicals, making it very less tedious, and also being cheaper in comparison with the method currently in use. The modified microtiter plate method as proposed here makes it far easier to screen the plant-growth-promoting character of plant-associated bacteria.
\end{abstract}

Keywords Siderophore $\cdot$ PGPR $\cdot$ CAS assay $\cdot$ Microplate · Plate reader

Naveen Kumar Arora

nkarora.bbau@gmail.com; nkarora_net@rediffmail.com

1 Rhizosphere Microbiology Laboratory, Department of Environmental Microbiology, BBA University, Lucknow, UP 226025, India

\section{Introduction}

Siderophores are low-molecular weight secondary metabolites with iron-chelating potential. These are compounds with small peptidic molecules having side chains and functional groups which have high-affinity ligand to bind ferric ions and transport them through the cell membrane (Raymond et al. 2015; Niehus et al. 2017). Siderophores are produced by various microorganisms and are classified into four main classes (carboxylate, hydroxamates, catecholates, and mixed type) on the basis of their structural features, functional groups, and types of ligands (Table 1) (Ali and Vidhale 2013; Kumar et al. 2017; Miethke and Marahiel 2007; Aznar et al. 2015). Diverse bacterial and fungal genera ranging from human pathogens to environmental microbes such as plant-growth-promoting rhizobacteria (PGPR) are reported to produce siderophores.

One of the key mechanisms of PGPR in promoting plant growth involves the production of secondary metabolites such as siderophores (Verma et al. 2011; Ghavami et al. 2017). Although iron is abundantly available in soil, most of it is unavailable to the plant or other organisms, because it forms insoluble complexes. Hence, iron deficiency is a major global issue. Siderophores produced by PGPR help in fulfilment of the iron requirement of plants by causing its solubilisation and chelation from organic or inorganic complexes present in soil (Wandersman and Delepelaire 2004; Arora et al. 2013; Singh et al. 2017). Microbial siderophores strongly chelate iron and enhance iron uptake by forming a ferric-siderophore complex even at very low concentrations (Dimkpa et al. 2009; Fernández-Scavino and Pedraza 2013; Boiteau et al. 2016). Siderophores thus not only help in enhancing plant growth, but also play a very important role in providing iron to other organisms including humans. Siderophores produced by PGPR also 
Table 1 Type of siderophores produced by plant-growth-promoting bacteria. Modified from Saha et al. (2015)

\begin{tabular}{lllll}
\hline $\begin{array}{l}\text { S. } \\
\text { no. }\end{array}$ & $\begin{array}{l}\text { Siderophore } \\
\text { type }\end{array}$ & Characteristic functional group & Example with microbial source & References \\
\hline 1 & Hydroxamate & $\begin{array}{c}\text { Esters or acid chlorides or carboxylic } \\
\text { acids } \\
\text { Phenolate or 2,3-dihydroxy benzoate } \\
\text { (DHB) binding groups }\end{array}$ & $\begin{array}{c}\text { Ferrioxamine B-Pseudomonas } \\
\text { fluorescence } \\
\text { Enterobactin-Escherichia coli }\end{array}$ & $\begin{array}{c}\text { (Maurer et al. 1968); Radhakrishnan et al. } \\
\text { (2014) } \\
\text { Dave et al. (2006); Grobelak and Hiller (2017) }\end{array}$ \\
3 & Catecholates & Rhizobactin-Rhizobium meliloti & $\begin{array}{c}\text { Smith and Neilands (1984); Ghavami et al. } \\
\text { (2017) }\end{array}$ \\
4 & Mixed type & $\begin{array}{c}\text { Mixture of above mentioned } \\
\text { functional groups }\end{array}$ & $\begin{array}{c}\text { Pyoverdine-Pseudomonas } \\
\text { aeruginosa }\end{array}$ & $\begin{array}{c}\text { Leong } \\
\text { Raffatellu (2016) }\end{array}$
\end{tabular}

help in protection of plant from phytopathogens (Arora 2015; Saha et al. 2016). Phytopathogens are inhibited in rhizosphere by siderophore-producing PGPR because of iron starvation or due to competitive exclusion in irondeficient conditions (Beneduzi et al. 2012; Parmar and Chakraborty 2016; Dalvi and Rakh 2017). Besides plant growth promotion, siderophores also play an important role in bioremediation of heavy metals from contaminated sites by binding to the toxic metals such as $\mathrm{Cr}^{3+}, \mathrm{Al}^{3+}, \mathrm{Pb}^{2+}$, $\mathrm{Cd}^{2+}, \mathrm{Hg}^{2+}$, etc. (Saha et al. 2015). Siderophore-producing microorganisms can thus be used to detoxify heavy metal contamination by mobilization of insoluble heavy metals (Dimkpa et al. 2008; Rajkumar et al. 2010; Hao et al. 2014; Mishra et al. 2017). Siderophore-producing microbes can thus be used in a variety of ways including bioremediation, sustainable agriculture as biosensors, and even in medicine.

Siderophore production ability of microorganisms is commonly detected by the chrome azurol sulphonate (CAS) assay as given by Schwyn and Neilands (1987). For quantitative estimation of siderophore production, supernatants of microbial cultures are used. Solid CAS agar media are also used for detection of siderophore production qualitatively (Raaska et al. 1993). In CAS assay, competition is for iron uptake between the siderophore and ferric complex of the CAS dye (CAS-iron-detergent complex). Siderophore strongly chelate the iron from iron-dye complex and dye becomes free in the media which causes change in colour from blue to orange (Louden et al. 2011).

Quantity of siderophore produced by microorganisms is measured by spectrophotometric estimation. In this traditional method, CAS reagent is mixed with microbial supernatant and amount of siderophore is estimated by taking optical density of each sample individually. However, this method requires large amount of chemical, time, labour, and space. Keeping this in mind, a modified method of siderophore estimation was developed which is far cheaper, time saving, and less laborious. This method of quantitative estimation of siderophore production was developed principally from the classical method of Schwyn and Neilands (1987) using 96 well microtiter plate and plate reader thus enabling the screening of several PGP strains at a time.

\section{Materials and methods}

\section{Bacteria and growth conditions}

In the present study, 23 siderophore-producing bacterial strains were taken from Culture Collection of Rhizosphere Microbiology Laboratory, Department of Environmental Microbiology, BBA University, Lucknow (Uttar Pradesh, India). Bacterial strains were grown on Luria-Bertani (LB) agar media (Himedia, Mumbai) at $28^{\circ} \mathrm{C}$ for $48 \mathrm{~h}$. All strains were preserved in LB slants at $4{ }^{\circ} \mathrm{C}$ and in $25 \%$ glycerol stock solution at $-80^{\circ} \mathrm{C}$.

\section{Siderophore estimation assay}

Bacterial strains were checked for siderophore-producing ability by universal CAS assay (Schwyn and Neilands 1987). Before starting the experiment, glassware was rinsed with $3 \mathrm{~mol} / \mathrm{l}$ hydrochloric acid $(\mathrm{HCl})$ to remove iron and subsequently washed in deionized water (Cabaj and Kosakowska 2007). Both qualitative and quantitative methods were used to estimate the siderophore production by bacterial strains. For both the methods, CAS reagent was prepared as per Schwyn and Neilands (1987). Briefly, $121 \mathrm{mg}$ CAS was dissolved in $100 \mathrm{ml}$ distilled water and $20 \mathrm{ml}$ of $1 \mathrm{mM}$ ferric chloride $\left(\mathrm{FeCl}_{3} \cdot 6 \mathrm{H}_{2} \mathrm{O}\right)$ solution prepared in $10 \mathrm{mM} \mathrm{HCl}$. This solution was added to $20 \mathrm{ml}$ hexadecyl trimethyl ammonium bromide (HDTMA) solution under stirring. HDTMA solution was prepared by mixing $729 \mathrm{mg}$ HDTMA in $400 \mathrm{ml}$ distilled water. The CAS-HDTMA solution was sterilized before further use.

\section{Qualitative method}

This assay was performed according to modified method given by $\mathrm{Hu}$ and $\mathrm{Xu}$ (2011). CAS agar plates were prepared 
by mixing $100 \mathrm{ml} \mathrm{CAS} \mathrm{reagent} \mathrm{in} 900 \mathrm{ml}$ sterilized LB agar medium. Four bacterial strains were spot inoculated on each plate. An un-inoculated plate was taken as control. After inoculation, plates were incubated at $28^{\circ} \mathrm{C}$ for 5-7 days and observed for the formation of orange zone around the bacterial colonies (Louden et al. 2011).

\section{Quantitative method}

Quantitative estimation of siderophore production by bacterial strain was done by (i) traditional method and (ii) modified microplate method.

\section{Traditional method}

Quantitative estimation of siderophore was done by taking supernatant of bacterial cultures grown in LB broth medium (Hu and $\mathrm{Xu} 2011)$. For this, $1 \mathrm{ml}$ broth was taken in $1.5 \mathrm{ml}$ centrifuge tube (Thomas Scientific, US) (one for each bacterial culture) and after sterilization inoculated with $10 \mu \mathrm{l}$ of freshly grown bacterial culture $\left(10^{8}\right.$ colony forming units (cfu) per $\mathrm{ml}$ ). Four replicates (tubes) were taken for each strain. Apart from this, control tube (uninoculated broth) was also maintained. After incubation at $28^{\circ} \mathrm{C}$ for $48 \mathrm{~h}$, bacterial cultures were centrifuged at $10,000 \mathrm{rpm}$ for $10 \mathrm{~min}$, cell pellets were discarded, and supernatant was used to estimate siderophore. Supernatant $(0.5 \mathrm{ml})$ of each bacterial culture was mixed with $0.5 \mathrm{ml}$ CAS reagent and after 20 min optical density was taken at $630 \mathrm{~nm}$ (Spectrophotometer: Thermo Scientific, Evolution 201). Siderophore produced by strains was measured in percent siderophore unit (psu) which was calculated according to the following formula (Payne 1993):

Siderophore production $(\mathrm{psu})=\frac{\left(A_{\mathrm{r}}-A_{\mathrm{s}}\right) \times 100}{A_{\mathrm{r}}}$,

where $A_{\mathrm{r}}=$ absorbance of reference (CAS solution and uninoculated broth), and $A_{\mathrm{s}}=$ absorbance of sample (CAS solution and cell-free supernatant of sample).

\section{Modified microplate method}

The modified method for estimating siderophore production was carried out using microtiter plate. Supernatant was obtained from $0.5 \mathrm{ml}$ inoculated $(5 \mu$ inoculum containing $10^{8} \mathrm{cfu} / \mathrm{ml}$ ) broth in microcentrifuge tube (Thomas Scientific, US). Supernatant $(100 \mu \mathrm{l})$ of each bacterial culture was added in separate wells of microplate (CLS3474 Sigma) followed by the addition of $100 \mu$ CAS reagent. After incubation, optical density of each sample (placed in wells of microplate) was recorded at $630 \mathrm{~nm}$ using microplate reader (Spectra Max M5e). Four replicates were taken for each strain in 96 well plate and siderophore estimated by the same formula as mentioned above.

\section{Correlation analysis between traditional method and modified microplate method}

Correlation between the data obtained from both the methods (traditional method and microplate method) was calculated to observe the similarity. Correlation coefficient was checked by software statistical package for the social science (SPSS) (2016) for windows.

\section{Results and discussion}

\section{Bacterial strains}

The 23 siderophore-producing bacterial strains taken in the study belong to species amongst diverse genera including Pseudomonas, Rhizobium, Enterobacter, Chronobacter, Kosakonia, Beijerinckia, and Pantoea. Details of the strains taken in the study with accession number and reference are mentioned in Table 2. All of these bacterial genera and species are well-known PGPR (Farina et al. 2012; Ahemad and Kibret 2014; Majeed et al. 2015; Naqqash et al. 2016) and common inhabitants of rhizosphere. The study also included endophytic strains from family Enterobacteriaceae, namely, $E$. cloacae, $P$. agglomerans, and $C$. sakazakii which are earlier reported to be siderophore producers (Mokracka et al. 2004; Grim et al. 2012; Walpola and Yoon 2013; Pandey et al. 2016). A novel PGPR strain of Kosakonia pseudosacchari, which has not been reported to produce siderophore earlier, was also included in this study. The study thus included very diverse PGPR from different locations of plants including rhizosphere, root nodules, and plant tissues (endophyte) (Table 2).

\section{Siderophore estimation}

Formation of orange-coloured zone around the bacterial colonies was observed which indicated siderophore production by bacterial strains. It was observed that all the bacterial strains taken in the study were positive for siderophore production. KA19 ( $P$. aeruginosa) showed maximum siderophore production ability on CAS agar (Table 3). The production of siderophore was roughly estimated on the basis of size of halo formation on CAS agar. CAS agar method can only give rough idea and is not a perfect method for quantification of siderophore production. Hence, quantitative estimation of siderophore is done using liquid culture media and CAS reagent. 
Table 2 Detail of bacterial strains used for siderophore production assay

\begin{tabular}{|c|c|c|c|c|c|}
\hline $\begin{array}{l}\text { S. } \\
\text { no. }\end{array}$ & Bacterial strains & Host plant & Collection site & $\begin{array}{l}\text { Accession number } \\
\text { (Genbank/ } \\
\text { MTCC/MCC) }\end{array}$ & References \\
\hline 1 & P. aeruginosa (KA19) & Brassica campestris & Rhizospheric soil & - & $\begin{array}{l}\text { Mishra and Arora } \\
\text { (2012a) }\end{array}$ \\
\hline 2 & P. aeruginosa (TO3) & - & Rhizospheric soil & FJ685995 & Khare and Arora (2010) \\
\hline 3 & $\begin{array}{l}\text { Kosakonia pseudosacchari } \\
\quad(\mathrm{LN})\end{array}$ & Leucaena leucocephala & Root nodule & KY392997 & - \\
\hline 4 & P. fluorescence (JM1) & - & Rhizospheric soil & KT734728 & - \\
\hline 5 & Enterobacter cloacae (CV5) & Crotalaria juncea & Root nodule & MF416432 & - \\
\hline 6 & Pseudomonas sp. (NDN1) & $\begin{array}{l}\text { Lycopersicum } \\
\text { esclantum }\end{array}$ & Rhizospheric region & - & Arora et al. (2008) \\
\hline 7 & P. aeruginosa (RB1) & Withania somnifera & $\begin{array}{l}\text { Plant tissue } \\
\text { Endophyte }\end{array}$ & KT761191 & - \\
\hline 8 & Kosakonia sp. (ClU1) & Clitoria ternatea & Root nodule & KY392994 & - \\
\hline 9 & E. cloacae (ClU2) & C. ternatea & Root nodule & KY178303 & - \\
\hline 10 & R. meliloti $\left(\mathrm{RMP}_{3}\right)$ & Mucuna pruriens & Root nodule & - & Arora et al. (2001) \\
\hline 11 & R. meliloti $\left(\mathrm{RMP}_{5}\right)$ & M. pruriens & Root nodule & - & Arora et al. (2001) \\
\hline 12 & Rhizobium sp. (RASH6) & Leguminous plant & Root nodule & - & Singh et al. (2014) \\
\hline 13 & P. fluorescence (TO7) & Brassica sp. & Rhizospheric soil & HQ457044 & $\begin{array}{l}\text { Mishra and Arora } \\
\text { (2012b) }\end{array}$ \\
\hline 14 & Pantoea agglomerans (CV2) & Crotalaria juncea & Root nodule & KY178304 & - \\
\hline 15 & Rhizobium pusense (LM) & L. leucocephala & Root nodule & KY392995 & - \\
\hline 16 & R. pusense (AB3) & Abrus precatorius & Root nodule & $\begin{array}{l}\text { KY392993 } \\
\text { MCC } 3409\end{array}$ & - \\
\hline 17 & P. tropicalis $(\mathrm{EKi})$ & L. esclantum & Rhizospheric soil & $\begin{array}{l}\text { FJ816019 } \\
\text { MTCC } 9737\end{array}$ & Khare et al. (2011) \\
\hline 18 & Cronobacter sakazakii (CGJ) & C. juncea & Root nodule & MF416433 & - \\
\hline 19 & P. aeruginosa (PF07) & Helianthus annus & Rhizospheric & - & $\begin{array}{l}\text { Tewari and Arora } \\
\text { (2014a) }\end{array}$ \\
\hline 20 & $P$. aeruginosa $(\mathrm{PF} 23)$ & - & Rhizospheric soil & KF598858 & $\begin{array}{l}\text { Tewari and Arora } \\
\text { (2014b) }\end{array}$ \\
\hline 21 & Beijerinckia fluminensis (AB1) & Abrus precatorius & Root nodule & MF400858 & - \\
\hline 22 & Rhizobium radiobacter (LB2) & L. leucocephala & Root nodule & KY392996 & - \\
\hline 23 & P. fluorescence (PF17) & H. annus & Rhizospheric soil & KU201600 & Tewari and Arora (2016) \\
\hline
\end{tabular}

In the traditional method, after growth, cell-free supernatant $(0.5 \mathrm{ml})$ is taken for spectrophotometric estimation in cuvette. However, in the proposed method, supernatant (only $100 \mu \mathrm{l}$ ) was poured in wells of microtiter plate. While $0.5 \mathrm{ml}$ CAS reagent was used per tube in the traditional method, only $100 \mu \mathrm{l}$ was employed in case of microplate method. Thus, there was drastic reduction in the amount of reagents and broth being used. In fact, there is $80 \%$ reduction in the requirement for CAS reagent and $50 \%$ decrease in the amount of broth used. Apart from this, the proposed method required far less time. As per our calculation in terms of total time required to quantify the siderophore produced (after incubation and centrifugation to get cell-free supernatant), there was $91.7 \%$ reduction.
Hence, the proposed method is not only more economical, but is also time saving (Table 4). By the 96 well microplate method, siderophore quantification can be done for several strains at one go (Fig. 1). Although other workers have also reported that microplate method is time saving and efficient (Lapinski et al. 1978; Frac et al. 2016), but this is the first report demonstrating the efficiency of 96 well microplate method for siderophore estimation in terms of time, money and being even more efficient than the traditional spectrophotometric method.

Amount of siderophore produced by all the 23 strains was checked and compared for both the traditional and proposed methods so as to determine the efficiency. The absorbance of reference $\left(A_{\mathrm{r}}\right)$ or control (un-inoculated 
Table 3 Results of siderophore production from bacterial strains and their estimation by qualitative analysis and quantitative analysis (traditional method and modified microplate method)

\begin{tabular}{|c|c|c|c|c|}
\hline \multirow[t]{2}{*}{ Bacterial strains } & \multirow{2}{*}{$\begin{array}{l}\text { Qualitative } \\
\text { analysis }\end{array}$} & \multicolumn{2}{|l|}{ Quantitative analysis } & \multirow{2}{*}{$\begin{array}{l}\% \text { increase in absorbance } \\
\text { by microplate method }\end{array}$} \\
\hline & & Traditional method (psu) & Microplate method (psu) & \\
\hline Control & & $1.12 \pm 0.01$ & $1.12 \pm 0.01$ & 0.00 \\
\hline KA19 & +++ & $69.16 \pm 0.71$ & $69.81 \pm 0.16$ & 0.93 \\
\hline TO3 & ++ & $41.45 \pm 0.44$ & $43.26 \pm 0.06$ & 4.18 \\
\hline $\mathrm{LN}$ & ++ & $40.44 \pm 0.59$ & $41.44 \pm 0.09$ & 2.41 \\
\hline JM1 & + & $24.99 \pm 0.60$ & $25.50 \pm 0.14$ & 2.00 \\
\hline CV5 & + & $35.51 \pm 0.53$ & $35.77 \pm 0.04$ & 0.72 \\
\hline NDN1 & + & $36.64 \pm 0.73$ & $37.35 \pm 0.12$ & 1.90 \\
\hline RB1 & ++ & $44.43 \pm 0.33$ & $44.44 \pm 0.16$ & 0.02 \\
\hline ClU1 & ++ & $30.39 \pm 0.18$ & $30.64 \pm 0.10$ & 0.81 \\
\hline ClU2 & + & $21.46 \pm 0.52$ & $21.90 \pm 0.15$ & 2.00 \\
\hline RMP3 & + & $24.12 \pm 0.62$ & $24.49 \pm 0.07$ & 1.51 \\
\hline RMP5 & ++ & $41.12 \pm 0.42$ & $41.35 \pm 0.05$ & 0.55 \\
\hline RASH6 & + & $14.13 \pm 0.24$ & $14.67 \pm 0.04$ & 3.68 \\
\hline TO7 & + & $22.58 \pm 0.60$ & $23.50 \pm 0.15$ & 3.91 \\
\hline $\mathrm{CV} 2$ & + & $27.82 \pm 0.52$ & $27.90 \pm 0.14$ & 0.06 \\
\hline $\mathrm{LM}$ & + & $12.63 \pm 0.15$ & $13.01 \pm 0.01$ & 2.92 \\
\hline AB3 & + & $33.34 \pm 0.03$ & $33.61 \pm 0.03$ & 0.80 \\
\hline $\mathrm{EKi}$ & ++ & $47.19 \pm 0.72$ & $47.43 \pm 0.18$ & 0.50 \\
\hline CGJ & + & $32.55 \pm 0.47$ & $33.06 \pm 0.15$ & 1.54 \\
\hline PF07 & + & $27.62 \pm 0.37$ & $27.71 \pm 0.07$ & 0.32 \\
\hline PF23 & ++ & $45.99 \pm 0.59$ & $46.33 \pm 0.09$ & 0.73 \\
\hline $\mathrm{AB} 1$ & + & $07.97 \pm 0.58$ & $08.33 \pm 0.08$ & 4.32 \\
\hline LB2 & ++ & $45.12 \pm 0.05$ & $45.64 \pm 0.04$ & 1.13 \\
\hline PF17 & ++ & $48.42 \pm 0.26$ & $49.54 \pm 0.13$ & 2.26 \\
\hline
\end{tabular}

Data are represented by the mean of four replicates \pm standard deviation, $(+++)$, high production; $(++)$, medium production; $(+)$, low production

Table 4 Comparative analysis between traditional and microplate methods of siderophore estimation

\begin{tabular}{lll}
\hline Comparative analysis & Methods & \\
\cline { 2 - 3 } & Traditional method & Microplate method \\
\hline Labour & Requires high labour input & Requires less labour input \\
Media & $96 \mathrm{ml}$ & $48 \mathrm{ml}$ \\
Reagent & $48 \mathrm{ml}$ & $9.6 \mathrm{ml}$ \\
(for 23 strains plus control in quadruplicates) & & \\
Accuracy & Less accurate because several samples & $\begin{array}{c}\text { More accurate because several samples (96) } \\
\text { can be handled collectively in only one } \\
\text { Time }\end{array}$ \\
\hline
\end{tabular}

broth and CAS reagent) was significantly similar both in case of traditional and modified microplate method. Concentration of siderophore produced by bacterial strains varied from $7.97 \pm 0.58$ to $69.16 \pm 0.71$ psu when measured by the traditional method, while when quantified through the proposed microplate method, it was from 


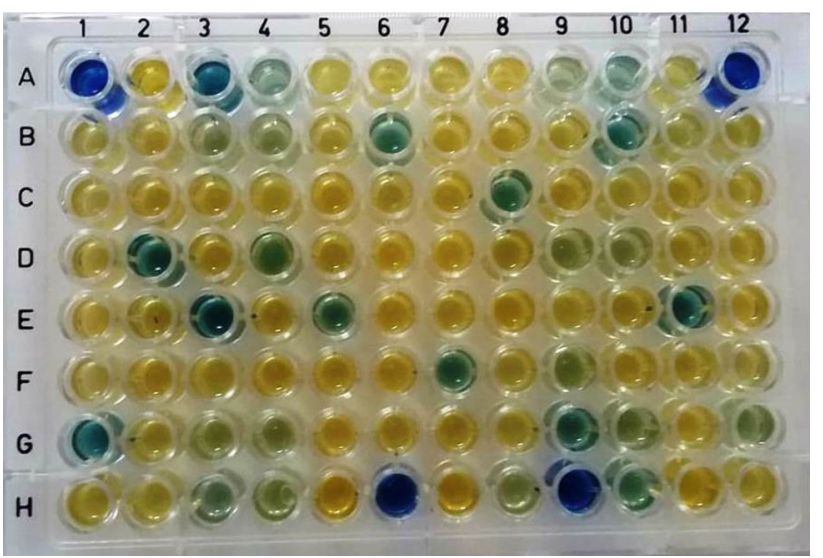

Fig. 1 Estimation of siderophore production by microplate method. Diverse bacterial strains producing different amounts of siderophore

$8.33 \pm 0.08$ to $69.81 \pm 0.16$ psu (Table 3 ). Quantitatively also $P$. aeruginosa (KA19) produced maximum amount of siderophore and the readings were significantly similar whether taken by spectrophotometer (traditional method) or by the microplate reader (proposed method). In fact, for all the 23 strains, results were significantly similar whether checked spectrophotometrically or by microplate reader (Table 3). This proves the similarity of both the methods.

Results by both the methods indicated that different strains showed variable siderophore-producing abilities. The present study also proved that fluorescent pseudomonads were the most proficient siderophore producers in comparison with other strains. Many researchers have reported fluorescent pseudomonads to be prolific producers of siderophores (Pandey et al. 2005; Subramanian and Satyan 2014; Pattan et al. 2017; Kotasthane et al. 2017). In fact, $P$. aeruginosa are amongst the most efficient producers of siderophores reported from rhizosphere or other habitats as shown by this work also (de Villegas et al. 2002; Unni et al. 2014; Sasirekha and Srividya 2016). Strains of $P$. aeruginosa (including TO3, RB1, and PF23) were found to be most efficient siderophore producers in comparison with others. Members of the family Rhizobiaceae (except $R$. radiobacter LB2 and $R$. meliloti RMP5) were not very efficient producers of siderophore, and in general, also researchers have not found rhizobia to be prolific producers of siderophores (Joseph et al. 2007; de Souza et al. 2015). Very few studies report that rhizobia are good producers of siderophores (Berraho et al. 1997; Arora et al. 2001; Duhan 2013; Wdowiak-Wróbel et al. 2017). Endophytic strain $K$. pseudosacchari $(\mathrm{LN})$ is being reported for the first time as an efficient siderophore producer. Although production of siderophore is a common phenomenon among PGPR present in rhizosphere (Tewari and Arora 2013; de Souza et al. 2015), recent researches have also shown their production by endophytes residing in the plant tissues and role in plant growth promotion (Zhao et al. 2015; Santoyo et al. 2016; Perez-Rosales et al. 2017).

\section{Correlation analysis between traditional and modified microplate method}

Correlation between both the methods was checked so as to measure the similarity between them. It was found that data from both the methods were highly correlated with each other with $R$ value of 0.999 (Fig. 2). This is a very strong positive correlation. The value of coefficient of determination $\left(R^{2}\right)$ was 0.999 which indicates that both methods were almost similar in efficiency; however, microplate method is far more rapid and economical. In addition, if the results of quantification by both the methods are observed, it can be seen that microplate method shows slightly higher readings (ranging from 0.02 to $4.32 \%$ ) in case of all the strains. This proves that microplate method is more accurate in comparison with traditional spectrophotometric method. This may be because absorbance of all the samples was taken at one go using 96 well microplate which reduced the handling error when compared to the traditional method, where absorbance of all the samples is taken

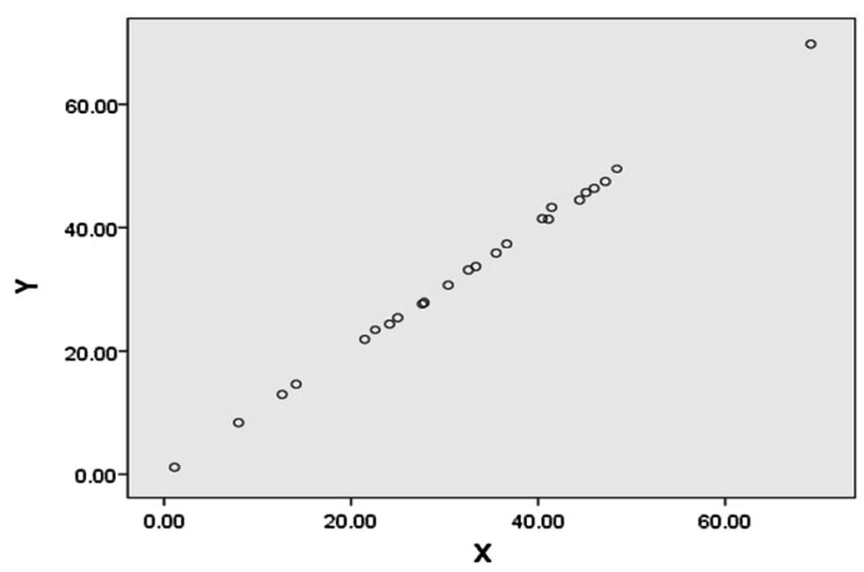

Fig. 2 Correlation between results of siderophore production by two methods: (i) Traditional method $=X$ value and (ii) Microplate method $=Y$ value 
individually. The accuracy factor was further confirmed by small value of standard deviation (SD) in case of microplate method (SD was within 0.18) compared to the traditional method (SD up to 0.73).

Since the classical assay given by Schwyn and Neilands (1987) to check the siderophore activity by bacteria and fungi, some modifications have appeared from time to time (Ames-Gottfred et al. 1989; Milagres et al. 1999; Machuca and Milagres 2003; Pérez-Miranda et al. 2007; Hu and Xu 2011). However, all these modifications were mainly for qualitative analysis only and were not for quantitative estimation. However, here we report a far more economical, time saving, and accurate method for quantitative estimation of siderophore by microbes.

\section{Conclusion}

Siderophore production is considered a very important trait of PGPR involved both in growth promotion and in biocontrol of phytopathogens. Siderophore production is also known by other groups of microbes including other soil bacteria and human pathogens. Traditionally, siderophore production and quantification is done by colorimetric/ spectrophotometric method. However, in the present study, 96 well microplate method using microplate reader is proposed for estimation of siderophore production by bacteria. The proposed method is far cheaper, consumes less time, and is even more accurate. The suggested method can be used for quantification of siderophore by any bacteria as a better alternative of the routine colorimetric method. Saving chemicals (particularly CAS dye), the proposed method will also be far less harmful to the environment.

\section{Compliance with ethical standards}

Conflict of interest The authors declare that they have no conflict of interest in the publication.

Open Access This article is distributed under the terms of the Creative Commons Attribution 4.0 International License (http:// creativecommons.org/licenses/by/4.0/), which permits unrestricted use, distribution, and reproduction in any medium, provided you give appropriate credit to the original author(s) and the source, provide a link to the Creative Commons license, and indicate if changes were made.

\section{References}

Ahemad M, Kibret M (2014) Mechanisms and applications of plant growth promoting rhizobacteria: current perspective. J King Saud Univ Sci 26:1-20

Ali SS, Vidhale NN (2013) Bacterial siderophore and their application: a review. Int J Curr Microbiol Appl Sci 2:303-312
Ames-Gottfred NP, Christie BR, Jordan DC (1989) Use of the chrome azurol $\mathrm{S}$ agar plate technique to differentiate strains and field isolates of Rhizobium leguminosarum biovar trifolii. Appl Environ Microbiol 55:707-710

Arora NK (ed) (2015) Plant Microbes Symbiosis: applied facets. Springer, India, p 381

Arora NK, Kang SC, Maheshwari DK (2001) Isolation of siderophore inducing strains of Rhizobium meliloti and their biocontrol potential against Macrophomina phaseolina that causes charcoal rot of ground nut. Curr Sci 81:673-677

Arora NK, Khare E, Verma A et al (2008) In vivo control of Macrophomina phaseolina by a chitinase and $\beta$-1,3-glucanaseproducing pseudomonad NDN1. Symbiosis 46:129-135

Arora NK, Tewari S, Singh R (2013) Multifaceted plant-associated microbes and their mechanisms diminish the concept of direct and indirect PGPRs. In: Arora NK (ed) Plant microbe symbiosis-fundamentals and advances. Springer, India, pp 411-449

Aznar A, Chen NW, Thomine S, Dellagi A (2015) Immunity to plant pathogens and iron homeostasis. Plant Sci 240:90-97

Behnsen J, Raffatellu M (2016) Siderophores: more than stealing iron. M Bio 7(6):e01906-e01916

Beneduzi A, Ambrosini A, Passaglia LM (2012) Plant growth promoting rhizobacteria (PGPR): their potential as antagonists and biocontrol agents. Genet Mol Biol 35:1044-1051

Berraho EL, Lesueur D, Diem HG et al (1997) Iron requirement and siderophore production in Rhizobium ciceri during growth on an iron-deficient medium. World J Microbiol Biotechnol 13(5):501-510

Boiteau RM, Mende DR, Hawco NJ et al (2016) Siderophore-based microbial adaptations to iron scarcity across the eastern Pacific Ocean. Proc Natl Acad Sci 113(50):14237-14242

Cabaj A, Kosakowska A (2007) Iron-dependent growth of and siderophore production by two heterotrophic bacteria isolated from brackish water of the southern Baltic Sea. Microbiol Res 164(5):570-577

Dalvi SM, Rakh RR (2017) Siderophore producing Pseudomonas cf. monteilii 9 for assured biological control of Sclerotium rolfsii causing stem rot of groundnut. Biosci Discov 8(3):546-555

Dave BP, Anshuman K, Hajela P (2006) Siderophores of halophilic archaea and their chemical characterization. Ind J Exp Biol 44:340-344

de Souza R, Ambrosini A, Passaglia LM (2015) Plant growthpromoting bacteria as inoculants in agricultural soils. Genet Mol Biol 38(4):401-419

de Villegas MD, Villa P, Frias A (2002) Evaluation of the siderophores production by Pseudomonas aeruginosa PSS. Rev Latinoam Microbiol 44(3/4):112-117

Dimkpa CO, Svatoš A, Dabrowska P et al (2008) Involvement of siderophores in the reduction of metal-induced inhibition of auxin synthesis in Streptomyces spp. Chemosphere 74:19-25

Dimkpa CO, Merten D, Svatoš A et al (2009) Siderophores mediate reduced and increased uptake of cadmium by Streptomyces tendae $\mathrm{F} 4$ and sunflower (Helianthus annuus), respectively. J Appl Microbiol 107:1687-1696

Duhan JS (2013) Tn5 siderophore producing mutants of Rhizobium and its role in nitrogen fixation and iron uptake in pigeonpea. Afric J Microbiol Res 7(16):1459-1464

Farina R, Beneduzi A, Ambrosini A et al (2012) Diversity of plant growth-promoting rhizobacteria communities associated with the stages of canola growth. Appl Soil Ecol 55:44-52

Fernández-Scavino A, Pedraza RO (2013) The role of siderophores in plant growth-promoting bacteria. In: Maheshwari DK, Saraf M, Aeron A (eds) Bacteria in agrobiology: crop productivity. Springer, Heidelberg, pp 265-285 
Frąc M, Gryta A, Oszust K et al (2016) Fast and accurate microplate method (Biolog MT2) for detection of Fusarium fungicides resistance/sensitivity. Front Microbiol 7:489

Ghavami N, Alikhani HA, Pourbabaei AA et al (2017) Effects of two new siderophore-producing rhizobacteria on growth and iron content of maize and canola plants. J Plant Nut 40:736-746

Grim CJ, Kothary MH, Gopinath G et al (2012) Identification and characterization of Cronobacter iron acquisition systems. Appl Environ Microbiol 78(17):6035-6050

Grobelak A, Hiller J (2017) Bacterial siderophores promote plant growth: screening of catechol and hydroxamate siderophores. Int J Phytoremediation 19(9):825-833

Hao X, Taghavi S, Xie P et al (2014) Phytoremediation of heavy and transition metals aided by legume-rhizobia symbiosis. Int $\mathrm{J}$ Phytoremediation 16:179-202

Hu QP, Xu JG (2011) A simple double-layered chrome azurol S agar (SDCASA) plate assay to optimize the production of siderophores by a potential biocontrol agent Bacillus. Afr J Microbiol Res 5:4321-4327

Joseph B, Ranjan PR, Lawrence R (2007) Characterization of plant growth promoting rhizobacteria associated with chickpea (Cicer arietinum L.). Int J Plant Prod 2:141-152

Khare E, Arora NK (2010) Effect of indole-3-acetic acid (IAA) produced by Pseudomonas aeruginosa in suppression of charcoal rot disease of chickpea. Curr Microbiol 61(1):64-68

Khare E, Singh S, Maheshwari DK et al (2011) Suppression of charcoal rot of chickpea by fluorescent pseudomonas under saline stress condition. Curr Microbiol 62:1548-1553

Kotasthane AS, Agrawal T, Zaidi NW et al (2017) Identification of siderophore producing and cynogenic fluorescent Pseudomonas and a simple confrontation assay to identify potential bio-control agent for collar rot of chickpea. 3 Biotech 7:137

Kumar V, Menon S, Agarwal H et al (2017) Characterization and optimization of bacterium isolated from soil samples for the production of siderophores. Resour Eff Technol. doi:10.1016/j. reffit.2017.04.004

Lapinski FJ, Crowley KM, Merrit CA et al (1978) Use of microplate methods in paternity testing. Am J Clin Pathol 70(5):766-769

Leong SA, Neilands JB (1982) Siderophore production by phytopathogenic microbial species. Arch Biochem Biophys 281:351-359

Louden BC, Haarmann D, Lynne AM (2011) Use of blue agar CAS assay for siderophore detection. $\mathrm{J}$ Microbiol Biol Educ 12(1):51-53

Machuca A, Milagres AM (2003) Use of CAS-agar plate modified to study the effect of different variables on the siderophore production by Aspergillus. Lett Appl Microbiol 36:177-181

Majeed A, Abbasi MK, Hameed S et al (2015) Isolation and characterization of plant growth-promoting rhizobacteria from wheat rhizosphere and their effect on plant growth promotion. Front Microbiol 6:198. doi:10.3389/fmicb.2015.00198

Maurer B, Muller A, Keller-Schierlein W et al (1968) Ferribactin, ein siderochrom aus Pseudomonas fluorescens Migula. Arch Microbiol 60:326-339

Miethke M, Marahiel MA (2007) Siderophore-based iron acquisition and pathogen control. Microbiol Mol Biol Rev 71:413-451

Milagres AM, Machuca A, Napoleao D (1999) Detection of siderophores production from several fungi and bacteria by a modification of chrome azurol S (CAS) agar plate assay. J Microbiol Methods 37:1-6

Mishra S, Arora NK (2012a) Evaluation of rhizospheric Pseudomonas and Bacillus as biocontrol tool for Xanthomonas campestris pv campestris. World J Microbiol Biotechnol 28:693-702

Mishra S, Arora NK (2012b) Management of black rot in cabbage by rhizospheric Pseudomonas species and analysis of 2,4-diacetylphloroglucinol by qRT-PCR. Biol Control 61:32-39
Mishra J, Singh R, Arora NK (2017) Alleviation of heavy metal stress in plants and remediation of soil by rhizosphere microorganisms. Front Microbiol 8:1706

Mokracka J, Koczura R, Kaznowski A (2004) Yersiniabactin and other siderophores produced by clinical isolates of Enterobacter spp. and Citrobacter spp. FEMS Immunol Med Microbiol 40(1):51-55

Naqqash T, Hameed S, Imran A et al (2016) Differential response of potato toward inoculation with taxonomically diverse plant growth promoting rhizobacteria. Front Plant Sci 7:144. doi:10. 3389/fpls.2016.00144

Niehus R, Picot A, Oliveira NM et al (2017) The evolution of siderophore production as a competitive trait. Evolution 71(6):1443-1455

Pandey P, Kang SC, Gupta CP et al (2005) Rhizosphere competent Pseudomonas aeruginosa GRC1 produces characteristic siderophore and enhances growth of Indian mustard (Brassica campestris). Curr Microbiol 51(5):303-309

Pandey PK, Singh MC, Singh S et al (2016) Inside the plants: endophytic bacteria and their functional attributes for plant growth promotion. Int J Curr Microbiol Appl Sci 6(2):11-21

Parmar HY, Chakraborty H (2016) Effect of siderophore on plant growth promotion. Int J Appl Pure Sci Agric 2(3):60-68

Pattan J, Kajale S, Pattan S (2017) Isolation, production and optimization of siderophores (iron chilators) from Pseudomonas fluorescence NCIM 5096 and Pseudomonas from soil rhizosphere and marine water. Int J Curr Microbiol App Sci 6(3):919-928

Payne SM (1993) Iron acquisition in microbial pathogenesis. Trends Microbiol 1:66-69

Pérez-Miranda S, Cabirol N, George-Téllez R et al (2007) O-CAS, a fast and universal method for siderophore detection. J Microbiol Methods 70(1):127-131

Perez-Rosales E, Alcaraz-Meléndez L, Puente ME et al (2017) Isolation and characterization of endophytic bacteria associated with roots of jojoba (Simmondsia chinensis (Link) Schneid). Curr Sci 112(2):396-401

Raaska L, Viikari L, Mattila-Sandholm T (1993) Detection of siderophores in growing cultures of Pseudomonas spp. J Ind Microbiol 11:181-186

Radhakrishnan M, Samshath KJ, Balagurunathan R (2014) Hydroxamate siderophore from Bacillus sp SD12 isolated from iron factory soil. Curr World Environ 9(3):990

Rajkumar M, Ae N, Prasad MNV, Freitas H (2010) Potential of siderophore-producing bacteria for improving heavy metal phytoextraction. Trends Biotechnol 28:142-149

Raymond KN, Allred BE, Sia AK (2015) Coordination chemistry of microbial iron transport. Acc Chem Res 48:2496-2505

Saha M, Sarkar S, Sarkar B, Sharma BK, Bhattacharjee S, Tribedi P (2015) Microbial siderophores and their potential applications: a review. Environ Sci Pollut Res 23:3984-3999

Saha M, Sarkar S, Sarkar B et al (2016) Microbial siderophores and their potential applications: a review. Environ Sci Poll Res 23(5):3984-3999

Santoyo G, Moreno-Hagelsieb G, del Carmen OMM et al (2016) Plant growth-promoting bacterial endophytes. Microbiol Res 183:92-99

Sasirekha B, Srividya S (2016) Siderophore production by Pseudomonas aeruginosa FP6, a biocontrol strain for Rhizoctonia solani and Colletotrichum gloeosporioides causing diseases in chilli. Agric Nat Resour 50:250-256

Schwyn B, Neilands JB (1987) Universal chemical assay for the detection and determination of siderophores. Anal Biochem 160:47-56 
Singh S, Gupta G, Khare E et al (2014) Phosphate solubilizing rhizobia promote the growth of chickpea under buffering conditions. Int J Pure App Biosci 2(5):97-106

Singh R, Pandey DK, Kumar A et al (2017) PGPR isolates from the rhizosphere of vegetable crop Momordica charantia: characterization and application as biofertilizer. Int J Curr Microbiol App Sci 6(3):1789-1802

Smith MJ, Neilands JB (1984) Rhizobactin, a siderophore from Rhizobium meliloti. J Plant Nutr 7:449-458

Subramanian J, Satyan K (2014) Isolation and selection of fluorescent pseudomonads based on multiple plant growth promotion traits and siderotyping. Chil J Agric Res 74(3):319-325

Tewari S, Arora NK (2013) Transactions amongst microorganisms and plant in the composite rhizosphere habitat. In: Arora NK (ed) Plant microbe symbiosis-fundamentals and advances. Springer, India, pp 143-149

Tewari S, Arora NK (2014a) Talc based exopolysaccharides formulation enhancing growth and production of Hellianthus annuus under saline conditions. Cell Mol Biol 60(5):73-81

Tewari S, Arora NK (2014b) Multifunctional exopolysaccharides from Pseudomonas aeruginosa PF23 involved in plant growth stimulation, biocontrol and stress amelioration in sunflower under saline conditions. Curr Microbiol 69:484-494

Tewari S, Arora NK (2016) Fluorescent Pseudomonas sp. PF17 as an efficient plant growth regulator and biocontrol agent for sunflower crop under saline conditions. Symbiosis 68(1-3):99-108

Unni KN, Priji P, Sajith S et al (2014) Pseudomonas aeruginosa BUP2-a novel strain isolated from Malabari goat produces type 2 pyoverdine. Adv Biosci Biotechnol 5:874-885

Verma VC, Singh SK, Prakash S (2011) Bio-control and plant growth promotion potential of siderophore producing endophytic Streptomyces from Azadirachta indica. A Juss J Basic Microbiol 51:550-556

Walpola BC, Yoon MH (2013) Isolation and characterization of phosphate solubilizing bacteria and their co-inoculation efficiency on tomato plant growth and phosphorous uptake. Afric J Microbiol Res 7(3):266-275

Wandersman C, Delepelaire P (2004) Bacterial iron sources: from siderophores to hemophores. Ann Rev Microbiol 58:611-647

Wdowiak-Wróbel S, Marek-Kozaczuk M, Kalita M et al (2017) Diversity and plant growth promoting properties of rhizobia isolated from root nodules of Ononis arvensis. Antonie Van Leeuwenhoek 110(8):1087-1103

Zhao L, Xu Y, Lai XH et al (2015) Screening and characterization of endophytic Bacillus and Paenibacillus strains from medicinal plant Lonicera japonica for use as potential plant growth promoters. Braz J Microbiol 46(4):977-989 